\title{
The effect of conscious sedation on salivary alpha-amylase levels during third molar surgery
}

\author{
${ }^{1}$ Department of Anesthesiology and Reanimation, School \\ of Dentistry, Istanbul University, Istanbul, Turkey \\ ${ }^{2}$ Department of Oral and Maxillofacial Surgery, School \\ of Dentistry, Beykent University, Istanbul, Turkey \\ ${ }^{3}$ Biochemistry Department, School of Dentistry, Istanbul \\ University, Istanbul, Turkey \\ ${ }^{4}$ Oral and Maxillofacial Surgery Department, School of \\ Dentistry, Istanbul University, Istanbul, Turkey \\ ${ }^{5}$ Orthodontics Department, School of Dentistry, La \\ Sapienze University, Rome, Italy
}

Abdullah Tolga Şitilci ${ }^{1}$, Selin Gaş², Şule Batu ${ }^{3}$, Hümeyra Kocaelli Arıkan ${ }^{4}$, Büşra Bozbay ${ }^{5}$

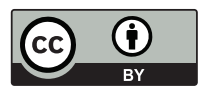

This work is licensed under a Creative Commons Attribution 4.0 International License

Received: 2020-02-10

Accepted: 2020-03-21

UDC: 618.1

J Clin Med Kaz 2020; 2(56):11-16

Corresponding author: Selin Gaş, DDS, PhD, Assistant Professor, Faculty of Dentistry, Beykent University, Beykent/Istanbul, 34550, Turkey. Tel.: +90 5064285734 E-mail: selingas@beykent.edutr, selin eren104@gmail.com

\section{ABSTRACT}

Aim: The aim of the present study was to investigate whether salivary alpha-amylase levels could be decreased by conscious sedation in the patients undergoing impacted third molar extraction.

Material and methods: A total of 18 male patients were recruited. All patients were administered the Modified Dental Anxiety Scale test. Patients were divided into a test group (procedures under sedation) and a control group (procedures under local anesthesia). Systolic blood pressure, diastolic blood pressure, oxygen saturation, and heart rate were monitored at different study time-points. Five samples of saliva were taken from each patient: the first time the patient came to the clinic, the patient sat in the chair for extraction, before local anesthesia, immediately after extraction, at $4 \mathrm{~h}$ after extraction.

Results: Although no statistically important difference was found for systolic blood pressure ( $>0.05$ ) between groups, postoperative diastolic blood pressure level of control group was statistically higher than the test group $(p=0.030)$. Also, a statistically significant decrease was found in the oxygen saturation level in postoperative time compared to preoperative time $(p<0.05)$.

Conclusion: Even though conscious sedation may be a solution for dental anxiety and phobia, our results indicated that sedation did not affect acute stress levels during oral surgery.

Key words: conscious sedation, dental anxiety, stress biomarkers, salivary alpha-amylase, tooth extraction \section{АЛЬФА-АМИЛАЗА ДЕНГЕЙІНЕ ӘСЕРІ \\ А.Т. Шитилджи ${ }^{1}$, С. Гаш ${ }^{2}$, Ш. Бату ${ }^{3}$, Х.К. Арикан ${ }^{4}$, Б. Бозбай ${ }^{5}$ \\ ${ }^{1}$ Анестезиология және реанимация кафедрасы, Стоматология мектебі, Ыстамбұл университеті, Ыстамбұл, Түркия \\ ${ }^{2}$ Бет-жақ хирургиясы кафедрасы, Стоматология мектебі, Университет Бейкент, Ыстамбұл, Түркия \\ ${ }^{3}$ Биохимия кафедрасы, Стоматология мектебі, Ыстамбұл университеті, Ыстамбұл, Түркия \\ ${ }^{4}$ Бет-жақ хирургиясы кафедрасы, Стоматология мектебі, Ыстамбұл университеті, Ыстамбұл, Түркия \\ ${ }^{5}$ Ортодонтия кафедрасы, Стоматология мектебі, Университет Ла Сапиенца, Рим, Италия}

ҮШІНШІ АЗУ ТІСТІ АЛЫП ТАСТАҒАНДА САНАНЫҢ САҚТАЛУЫМЕН СЕДАЦИЯНЫН СІЛЕКЕЙ БЕЗДЕРІНІҢ

\section{ТҰЖЫРЫМДАМА}

Мақсаты: Зерттеудің мақсаты ретинолярлық үшінші азу тісі алып тасталған пациенттерде есін сақтай отырып, седациядан кейін альфа-амилаза сілекей безінің азаюы мүмкін екендігін зерттеу болды.

Материалдар мен әдістер: Барлығы 18 ер адам іріктелді. Барлық пациенттер өзгертілген стоматологиялық процедураның қорқыныш шкаласы бойынша тексеруден өтті. Науқастар тәжірибелік топқа (седативті процедура) және бақылау тобына (жергілікті анестезиядағы процедура) бөлінді. Систолалық қан қысымы, диастолалық қан қысымы, оттегінің қанығуы, жүрек соғу жылдамдығы зерттеу уақытының әртүрлі нүктелерінде бақыланды. Әр пациенттен сілекейдің бес үлгісі алынды: пациент клиникаға келді, науқас алып тастау үшін орындыққа отырды, локальды анестезия алдында, шығарғаннан кейін, шығарылғаннан кейін 4 сағаттан кейін.

Нәтижелер: Топтар арасында систолалық қан қысымында статистикалық маңызды айырмашылық жоқ (р>0.05), бақылау тобындағы операциядан кейінгі диастолалық қысым деңгейі эксперименттік топқа қарағанда жоғары (p=0.030). Сонымен қатар, операциядан кейінгі уақытпен салыстырғанда оттегінің қанығу деңгейінің статистикалық тұрғыдан төмендегені анықталды (р<0.05).

Қорытынды: саналы седация стоматологиялық процедурадан қорқудың шешімі бола алатынына қарамастан, біздің нәтижелеріміз стоматологиялық операция кезінде өткір стресс деңгейіне әсер етпегенін көрсетті.

Негізгі сөздер: сақталған санамен седация, стоматологиялық процедуралардан қорқу, стресс биомаркерлері, сілекей безі альфаамилаза, тіс жұлу 
${ }^{1}$ Кафедра анестезиологии и реанимации, Школа стоматологии, Стамбульский университет, Стамбул, Турция

${ }^{2}$ Кафедра челюстнолицевой хирургии, Школа стоматологии, Университет Бейкент, Стамбул, Турция

${ }^{3}$ Кафедра биохимии, Школа стоматологии, Стамбульский университет, Стамбул, Турция

${ }^{4}$ Кафедра челюстнолицевой хирургии, Школа стоматологии, Стамбульский университет, Стамбул, Турция

${ }^{5}$ Кафедра ортодонтии, Школа стоматологии, Университет Ла Сапиенца, Рим, Италия

\section{PEЗЮME}

Цель: Целью настоящего исследования было изучить, может ли уровень альфа-амилазы слюнных желез снизиться после седации при сохраненном сознании у пациентов, подвергшихся удалению ретинированного третьего моляра.

Материалы и методы: Всего было отобрано 18 пациентов мужского пола. Все пациенты прошли тест модифицированной шкалы боязни стоматологической процедуры. Пациенты были разделены на экспериментальную группу (процедура под седацией) и контрольную группу (процедура под местной анестезией). Систолическое артериальное давление, диастолическое артериальное давление, насыщение кислородом и частота сердечных сокращений контролировались в разные моменты времени исследования. У каждого пациента было взято пять образцов слюны: пациент пришел в клинику, пациент сидел в кресле для удаления, перед местной анестезией, сразу после удаления, через 4 часа после удаления.

Результаты: Несмотря на то, что статистически значимого различия в отношении систолического артериального давления ( $>0,05)$ между группами обнаружено не было, уровень послеоперационного диастолического артериального давления в контрольной группе был статистически выше, чем в экспериментальной группе ( $(=0.030)$. Кроме того, обнаружено статистически значимое снижение уровня насыщения кислородом в послеоперационное время по сравнению с предоперационным временем $(p<0.05)$.

Заключение: Хотя сознательная седация может быть решением для боязни стоматологической процедуры, наши результаты показали, что она не повлияла на уровень острого стресса во время стоматологической операции.

Ключевые слова: седация при сохраненном сознании, боязнь стоматологической процедуры, биомаркеры стресса, альфа-амилаза слюнных желез, удаление зуба

\section{Introduction}

Dental treatments which are probably a reliable cause of stress, are often considered anxiety-producing and stressful events [1-3]. Dental anxiety has been registered with a prevalence of between $3 \%$ and $20 \%$ of the population [4]. The ability to perceive and cope with stress may vary according to genetics [5] gender and age [6]. Exogenous female hormones reveal estrogens to display an exacerbation effect in response to acute stress [7]. In oral and maxillofacial surgery, surgical extraction of impacted third molars is one of the most common surgical techniques performed in the oral cavity. Several factors such as complexity and duration of the surgery, the surgeon's technique, iatrogenic factors, can disturb patient comfort. These factors should be minimalized to increase satisfaction with the treatment, improve the quality of life and reduce the fear of surgical interventions [8]. Conscious intravenous sedation could be administered for the patients to provide anxiolysis, sedation, and analgesia for the patient.

Human saliva is a biological fluid with important diagnostic potential. As it can be collected non-invasively, it presents a viable alternative to blood, serum, or plasma [9-14]. Various proteins [15], hormones [16], antibodies [17], drugs [18], and cytokines [19] those were diffused from the blood are found in human saliva, so many compounds found in the blood are also transferred into saliva. Many of these arrays of proteins are useful for the detection and treatment of diseases [9]. As it suggests the composition of saliva can be influenced by systemic changes, specific biomarkers could help recognize certain pathologic conditions [16]. Recent studies have leaded how contains of saliva can aid in the diagnosis of cardiovascular disease, inflammation, hepatic damage, autoimmune disease, and insulin resistance [15, 20-23].

Salivary alpha-amylase (sAA) which reflect stressrelated changes in the autonomic nervous system (ANS), has been proposed as a non-invasive stress biomarker which produced by the parotid, submandibular and sublingual glands [24]. Unlike most diagnostically important salivary substances, sAA that displays distinct diurnal secretion patterns is directly influenced by symphatic innervation of the salivary gland. Several studies have investigated that changes in the levels of SAA as an indicator of dental anxiety during the extraction [25-
27]. There is lack of information about the effects of sedation on sAA levels at different time points during the operation of the impacted third molars.

Thus, the specific aims of the present study were to evaluate sAA responses to impacted third molar extractions at different time points in the patients under conscious sedation with local anesthesia and to examine the relationship between sAA, conscious sedation and dental anxiety.

\section{Material and methods}

A total of 20 male patients requiring impacted third molar extractions were initially considered for this study. Patients with sedation history were excluded. Women also were not included for this study because of their hormonal changes. The final study sample compromised 18 male subjects between 19 and 33 years of age. The saliva samples of the two patients were bloody, so they were excluded.

Complete anamnesis was collected and clinical examinations were done to determine infection, pu, swelling. Written informed consent forms were signed by all patients who agreed to participate in the study. The inclusion criteria for the study were the following: male patient with impacted third molar without relevant systemic pathology (ASA I as per the American Society of Anesthesiologists classification).

The study was approved by Local Ethic Committee (2018/24).

\section{Variables and data measurement}

Patients were divided into two groups: test group (procedures under sedation) and control group (procedures under local anesthesia). All patients were asked to fill MDAS form which consists of five questions: 'If you went to the dentist tomorrow, how would you feel?'; 'If you were sitting in the waiting room, waiting for treatment, how would you feel?'; 'If you were about to have a tooth drilled, how would you feel?'; 'If you were about to have your teeth scaled and polished, how would you feel?'; and 'If you were about to have a local anaesthetic injection in your gum, above an upper back tooth, how would you feel?'. The response alternatives ranged from 'not anxious' ( score $=1$ ) to extremely anxious ( score $=5$ ). The cut-off was set at $\geq 15$ for dental anxiety and as $\geq 19$ for being very dentally anxious, as described by Humphris et al. [28]. 
Systolic blood pressure (SBP), diastolic blood pressure (DBP), oxygen saturation (SO2), and heart rate (HR) were monitored at different time points: preoperative time ( $\mathrm{SBPa}$, $\mathrm{DBPa}, \mathrm{SO} 2 \mathrm{a}, \mathrm{HRa}$ ); intraoperative time - after local anesthesia ( $\mathrm{SBPb}, \mathrm{DBPb}, \mathrm{SO} 2 \mathrm{~b}, \mathrm{HRb}$ ), intraoperative time - after extraction (SBPc, DBPc, SO2c, HRc), postoperative time (SBPd, DBPd, $\mathrm{SO} 2 \mathrm{~d}, \mathrm{HRd}$ ). The first specimen of saliva was taken at the first time patient came to clinic (t1). Saliva was allowed to flow in the floor of mouth, $1 \mathrm{ml}$ was then collected using a Pasteur pipette. First day after examination, patient was given an appointment. The second time of the saliva was taken when the patient sat in the chair for extraction ( $\mathrm{t} 2$ ). The other times of saliva samples were taken before local anesthesia (t3), immediately after extraction (t4) and $4 \mathrm{~h}$ after extraction (t5). Due to the localization and position of the third molar, osteotomy was performed using a 20,000-rpm hand piece under irrigation for all patients. Some cases required tooth sectioning. 3-0 silk suture was used at the end of the surgery.

Ibuprofen (600 mg every $8 \mathrm{~h}$ for 7 days) and amoxicillin/ clavunate $(875 \mathrm{mg} / 125 \mathrm{mg}$ every $8 \mathrm{~h}$ for 5 days $)$ were prescribed. Detailed explanation of oral hygiene techniques and recommendations for the postoperative period were given to each patient.

\section{Measurement of sAA activity}

The sAA activity was measured by a colorimetric assay using 4,6-ethylidene-(G7)p-nitrophenyl-(G1)-Dmaltoheptaoside in an automatic analyzer (Cobas Integra 800, Roche, Basel, Switzerland) after 1/400 dilution of saliva in distilled water.

\section{Statistical analysis}

IBM Statistical Package for Social Sciences (SPSS) version 22 (IBM Corp., Armonk, NY, USA) software program was run. The normal distribution of the parameters was evaluated by Shapiro Wilks test and it was found that the parameters did not show normal distribution. Descriptive statistical methods (mean, standard deviation) as well as quantitative data were compared; Mann-Whitney U test was used for the comparison of the parameters between the two groups and Wilcoxon sign test was used for the intra-group comparisons of the parameters. Spearman's Rho correlation analysis was used to evaluate the relationships between the parameters. Statistical significance was set as $\mathrm{p}<0.05$.

\section{Results}

A total of 18 patients fulfilled the study criteria; 2 patients were excluded because of their bloody saliva samples. A total of 18 impacted third molar extractions were performed. All patients $(100 \%)$ were male; they ranged in age from 19 to 33 years. Only patients with a diagnosis of impacted third molars were selected for the study.

Each patient's SBP, DBP, SO2 and HR were recorded during surgical interventions (Table 1). Between groups, statistical analysis showed no correlation for SBP $(p>0.05)$. There was a statistically significant difference between DBPd in control group and test group $(\mathrm{p}<0.05)$. DBPd of control group was found statistically higher than test group ( $\mathrm{p}: 0.030)$. HR did not show significant correlation in both groups $(p>0.05)$. $\mathrm{SO} 2 \mathrm{~d}$ level compared to $\mathrm{SO} 2 \mathrm{a}$ showed a statistically significant decrease (p3:0.046).

Table 1

Average $( \pm$ SD) systolic blood pressure, diastolic blood pressure, heart rate, oxygen saturation levels at different study time-points

\begin{tabular}{|l|l|l|l|}
\hline & Test & Control & \\
\hline & Mean \pm SD (median) & Mean \pm SD (median) & $1 \mathrm{p}$ \\
\hline SBPa & $123,44 \pm 10,74(120)$ & $123 \pm 13,43(125)$ & 0,558 \\
\hline SBPb & $121,78 \pm 13,54(120)$ & $130,11 \pm 16,8(132)$ & 0,268 \\
\hline SBPc & $121,44 \pm 4,69(122)$ & $126,44 \pm 15,12(130)$ & 0,306 \\
\hline SBPd & $117,44 \pm 7,78(120)$ & $127,67 \pm 17,33(127)$ & 0,059 \\
\hline DBPa & $70,11 \pm 6,43(70)$ & $66 \pm 10,34(64)$ & 0,352 \\
\hline DBPb & $65,78 \pm 11,09(61)$ & $68,67 \pm 9,7(70)$ & 0,330 \\
\hline DBPc & $69 \pm 9,31(65)$ & $68,25 \pm 11,31(66,5)$ & 0,961 \\
\hline DBPd & $63 \pm 4,82(62) \neq$ & $71,56 \pm 8,89(70) \ddagger$ & $0,030^{*}$ \\
\hline HRa & $89 \pm 12,13(92)$ & $86,44 \pm 9,86(89)$ & 0,288 \\
\hline HRb & $83,11 \pm 10,68(80)$ & $89,89 \pm 10,42(87)$ & 0,185 \\
\hline HRc & $84 \pm 5,96(83)$ & $88,11 \pm 7,39(88)$ & 0,120 \\
\hline HRd & $82,33 \pm 6,28(80)$ & $89,67 \pm 10,36(88)$ & 0,184 \\
\hline SO2a & $99 \pm 0(99)$ & $99,44 \pm 0,53(99)$ & $0,028^{*}$ \\
\hline SO2b & $99,11 \pm 0,33(99)$ & $99,22 \pm 0,44(99)$ & 0,539 \\
\hline SO2c & $99 \pm 0(99)$ & $99,11 \pm 0,33(99)$ & 0,317 \\
\hline SO2d & $99 \pm 0(99)$ & $99 \pm 0,5(99) \neq$ & 1,000 \\
\hline
\end{tabular}

1Mann Whitney U Test

Intergroups Wilcoxon sign test $\mathrm{p}<0.05$ statistically significant $\quad * \mathrm{p}<0.05$

SD: Standart Deviation, SBP: Systolic Blood Pressure, DBP: Diastolic Blood Pressure, HR: Heart Rate, SO2: Oxygen Saturation

Preoperative time (SBPa, DBPa, SO2a, HRa); Intraoperative time-after local anesthesia (SBPb, DBPb, SO2b, HRb), Intraoperative time-after extraction (SBPc, DBPc, SO2c, HRc), Postoperative time (SBPd, DBPd, SO2d, HRd)

Statistical analysis showed no significant comparison according to sAA levels in different study time points between groups ( $p>0.05$ ) (Table 2$)$. In test group $\mathrm{t} 1$ and $\mathrm{t} 3$ in comparison, decrease of sAA level in $\mathrm{t} 3$ were significantly higher than $\mathrm{t} 1$ ( $\mathrm{p}: 0.048$ ). But when alpha-amylase level in $\mathrm{t} 1$ compared to $\mathrm{t} 2$, $\mathrm{t} 4$, $\mathrm{t} 5$, no statistically significant relationship was found between study time points ( 1 : $0.110, \mathrm{p} 2: 0.208, \mathrm{p} 3: 0.214 ; \mathrm{p}>0.05$ ). In addition, there was no statistically significant difference for sAA levels between $\mathrm{t} 1$ and $\mathrm{t} 2, \mathrm{t} 3, \mathrm{t} 4, \mathrm{t} 5$ in test group and there was no statistically significant correlation with sAA levels between $\mathrm{t} 1$ and $\mathrm{t} 2, \mathrm{t} 3, \mathrm{t} 4, \mathrm{t} 5$ in control group (p1:0.441, p2:0.139, p3:0.441, $\mathrm{p} 4: 0.314 ; \mathrm{p}>0.05)$. 


\begin{tabular}{|l|l|l|l|}
\hline & Test & Control & $1 \mathrm{p}$ \\
\hline Salivary Alpha-Amylase & Mean \pm SD & Mean \pm SD & \\
\hline $\begin{array}{l}\text { t1. The first time the patient came } \\
\text { to clinic }\end{array}$ & $851,22 \pm 723,25(717)$ & $589,78 \pm 330,5(550)$ & 0,566 \\
\hline $\begin{array}{l}\text { t2. When the patient sat in the chair } \\
\text { for extraction }\end{array}$ & $829,33 \pm 706,45(642)$ & $547,78 \pm 228,98(525)$ & 0,508 \\
\hline t3. Before local anesthesia & $541,78 \pm 431,2(440) \neq$ & $435,11 \pm 342,3(355)$ & 0,627 \\
\hline t4. Immediately after extraction & $685,11 \pm 404,55(440)$ & $710,78 \pm 486,15(467)$ & 0,895 \\
\hline t5. 4 h after extraction & $564,67 \pm 545,62(304)$ & $484,78 \pm 197,1(487)$ & 0,691 \\
\hline
\end{tabular}

* Statistically significant at $\mathrm{p}<0.05$

When the change in alpha amylase level between $t 1, t 4$ and 5 between two groups was examined; the alteration of sAA level between t1-t4 and t1-t5 was not found statistically significant $(\mathrm{p}>0.05)$.

\section{Discussion}

The specific aims of the present study were to determine the effect of conscious sedation on sAA levels and explain the relationship between sAAlevels, dental anxiety and hemodynamic changes (blood pressure, heart rate, oxygen saturation) in patients undergoing impacted third molar extraction. The study results showed that there was no statistically significant difference between dental anxiety and sAA level in patients at different study time-points both under conscious sedation and local anesthesia.

The surgical extraction of impacted third molars is known one of the most common surgeries performed in the oral and maxillofacial surgery field. The surgical difficulty of removal of the impacted third molars may cause a dental fear. From this starting point, sedation has been carried out by oral and maxillofacial surgeons [29]. The use of sedation in dental practice is commonly used to reduce anxiety so that collaboration with dentist for dental treatment may be achieved. Several dental-anxiety measures have been developed to help the dentist to manage anxious patients. Modified Dental Anxiety Scale (MDAS) has been developed by Humphris et al. for this reason [28]. Dental anxiety tests should be evaluated with various stress biomarkers such as cortisol, $\alpha$-amylase, $\operatorname{IgA}$, total protein for objective assessment. Nowadays saliva can be used as an easy, noninvasive method to analyze the levels of stress markers when compared with serum that is an invasive method [26]. Several studies investigated the concentrations of $\alpha$-amylase, IgA, cortisol, total protein in saliva to determine dental anxiety [26,30,31]. sAA constitute proxy measures of the hypothalamic-pituitary-adrenal axis and the autonomic nervous system [32]. Chatterton et al. reported that there was a correlation between the sAA and blood levels of catecholamines [33]. Therefore, the measurement of sAA concentration can give a clue about the level of stress. Also it is known that sAA activity peaks in response to mild to moderate level challenge within 10 minutes of the operation [34]. In our sAA levels at different study time points did not differ statistically in the groups. In addition MDAS test results and amylase levels in comparison did not show statistically significant correlation. Unlike our results, Furlan et al observed higher sAA levels before dental prophylaxis compared to after the procedure [31]. GutiérrezCorrales et al. analyzed the relationship between inflammatory response and sAA concentration in patients undergoing impacted lower third molar surgery. They found that sAA level $2 \mathrm{~h}$ after operation was higher than the preoperative value [27]. Although, in our study the decrease in the level of sAA just before the local anesthesia was statistically significant compared to the first time point, postoperative sAA levels did not differ from preoperative time points. The difference between two studies may be the time points when sAA levels were measured. Nater and Rohleder [24], Allwood et al. [35], and Kang [36] evaluated the relationship between stress conditions and the sAA concentration. They reported that stress causes significant increase in sAA concentration when patients were faced to a stressful position compared to a rest condition. In our study we found that anxiety levels revealed by MDAS did not affect sAA level. Regardless of the anxiety sense, biological stress could affect sAA. Perhaps conscious sedation is not a procedure that reduces biological stress markers caused by autonomic nervous system, so our study results may have shown that conscious sedation does not affect sAA levels.

A surgical dental procedures can cause anxiety which can affect the patient's psychological condition and thus increasing SBP and DBP. These hemodynamic changes in medically compromised patients may induce adverse cardiac effects. Hence, previous studies estimated that it could be useful to perform surgery with patients under conscious sedation in those with high levels of dental anxiety, as the hemodynamic variables are controlled by adjusting the dosage of the sedative drugs [37]. In our study, only DBP levels showed positive correlation in sedation and control groups at preoperative and postoperative times. Even though there was no statistically significant correlation with SBP in both groups at postoperative times, control groups had higher DBP levels prior to test group. Unlike this result, preoperative DBP level in control group had statistically important increment prior to postoperative DBP level. Although test group did not have statistically significant change in SOb level, in control group decrease of SO2d level was found statistically significant prior to SO2a level. Several studies also analyzed the hemodynamic changes in patients undergoing third molar surgery with local anesthesia. They reported statistically significant differences of hemodynamic variables [37-40]. However the present study failed to show overall perfect correlations between the dental anxiety level and hemodynamic variables. Because patients did not show any abnormalities. This is justified by the sedation carried out in which the levels of consciousness and dental anxiety are controlled.

Our study was the first to evaluate the correlations between MDAS, sAA and hemodynamic changes during impacted third molar surgery under conscious sedation and local anesthesia. In this study, we evaluated the effects of anxiety on biologic surgical stress and psychological stress on SAA. Anxiety was not increasing the impacts of biological surgical stress on sAA. These results can create question marks to start future designed future studies. 
The results of the present study should be viewed within the limitations of the data. First, the numbers of study time points should be increased. In the late healing period time, all measurements should be repeated. Second, the effects of general anesthesia, conscious sedation and local anesthesia on sAA levels and dental anxiety should be compared in the same study. Third different dental anxiety tests should be used to compare the results. Anxiety was recognized as different tests as cross. Also, using 19 limits, instead of 15 limits, according to MDAS, maybe give us different results.

We were informed about the patients' dental anxiety with the body language and verbal expressions of the patients and we monitored the anxiety with MDAS. These patients had not previously undergone conscious sedation. Therefore, we did not think that they would be able to abuse sedation. However, as a result of the study, we could not detect any systemic symptoms or monitorable anxiety symptoms except MDAS results and body language. In this case, even if we cannot monitor these fears, we believe that the answer to the question "Do we practice conscious sedation?" should be discussed.

\section{Conclusion}

In conclusion, conscious sedation is not a physiological stress reducing procedure. Based on the results of our study, no significant difference on sAA and dental anxiety levels were observed between the two anesthesia methods. Future researches should aim to explain the effects of general anesthesia, conscious sedation, local anesthesia on SAA and various stress markers in the same study and use different dental anxiety scales to confirm the study results. But future studies should compare the effects of general anesthesia and type of sedations on the alpha-amylase levels and other biomarkers that are not affected by the acute inflammatory process after extraction and explain the effects at early and late stages of the healing period.

Name of Trial Registry: Clinical Trial

Clinical Trial Registration Number: NCT0407515

Disclosures: There is no conflict of interest for all authors.

Sources of Funding: There is no funding.

\section{References}

1. Krueger TH, Heller HW, Hauffa BP, Haake P, Exton MS, Schedlowski M. The dental anxiety scale and effects of dental fear on salivary cortisol. Percept Mot Skills. 2005; 100(1):109-117. https://doi.org/10.2466/pms.100.1.109-117

2. Miller CS, Dembo JB, Falace DA, Kaplan AL. Salivary cortisol response to dental treatment of varying stress. Oral Surg Oral Med Oral Pathol. 1995; 79(4):436-441. https://doi.org/10.1016/S1079-2104(05)80123-4

3. Rayen R, Muthu MS, Chandrasekhar Rao R, Sivakumar N. Evaluation of physiological and behavioral measures in relation to dental anxiety during sequential dental visits in children. Indian J Dent Res. 2006; 17(1):27-34. https://doi.org/10.4103/0970-9290.29895

4. Locker D, Poulton R, Thomson WM. Psychological disorders and dental anxiety in a young adult population. Commun Dent Oral Epidemiol. 2001; 29(6):456-463. https://doi.org/10.1034/j.1600-0528.2001.290607.x

5. de Kloet ER, Sibug RM, Helmerhorst FM, Schmidt MV. Stress, genes and the mechanism of programming the brain for later life. Neurosci Biobehav Rev. 2005; 29(2):271-281. https://doi.org/10.1016/j.neubiorev.2004.10.008

6. Bale TL, Epperson CN. Sex differences and stress across the lifespan. Nat Neurosci. 2015; 18(10):1413-1420. https://doi.org/10.1038/ nn.4112

7. Viau V, Meaney MJ. The inhibitory effect of testosterone on hypothalamic-pituitary-adrenal responses to stress is mediated by the medial preoptic area. J Neurosci. 1996; 16(5):1866-1876. https://doi.org/10.1523/JNEUROSCI.16-05-01866.1996

8. Torres-Lagares D, Recio-Lora C, Castillo-Dalí G, Ruiz-de-León-Hernández G, Hita-Iglesias P, Serrera-Figallo MA,et al. Influence of state anxiety and trate anxiety in postoperative in oral surgery. Med Oral Patol Oral Cir Bucal. 2014; 19(4):e403-e408. https://doi. org/10.4317/medoral.19604

9. Hu S, Loo JA, Wong DT. Human body fluid proteome analysis. Proteomics. 2006; 23:6326-6353.https://doi.org/10.1002/pmic.200600284

10. Agha-Hosseini F, Shirzad N, Moosavi MS. Evaluation of xerostomia and salivary flow rate in Hashimoto's thyroiditis. Med Oral Patol Oral Cir Bucal. 2016; 21(1):e1-5. https://doi.org/10.4317/medoral.20559

11. Skrinjar I, Brailo V, Vidovic-Juras D, Vucicevic-Boras V, Milenovic A. Evaluation of pretreatment serum interleukin-6 and tu-mour necrosis factor alpha as a potential biomarker for recurrence in patients with oral squamous cell carcinoma. Med Oral Patol Oral Cir Bucal. 2015; 20(4):e402-e407. https://doi.org/10.4317/medoral.20373

12. Wei P, Li C, Qiang L, Li Z, Hua H. Role of salivary anti-SSA/B antibodies for diagnos-ing primary Sjögren's syndrome. Med Oral Patol Oral Cir Bucal. 2015; 20(2):e156-160. https://doi.org/10.4317/medoral.20199

13. Pereira DL, Vilela VS, Dos Santos TC, Pires FR. Clinical and laboratorial profile and histological features on minor salivary glands from patients under investigation for Sjögren's syndrome. Med Oral Patol Oral Cir Bucal. 2014; 19(3):e237-241. https://doi.org/10.4317/ medoral.19486

14. Bachmeier E, Mazzeo MA, López MM, Linares JA, Jarchum G, Wietz FM, et al. Mucositis and salivary antioxidants in patients undergoing bone marrow transplantation (BMT). Med Oral Patol Oral Cir Bucal. 2014; 19(5):e444-e450. https://doi.org/10.4317/ medoral.19062

15. Rahim MA, Rahim ZH, Ahmad WA, Hashim OH. Can saliva proteins be used to predict the onset of acute myocardial infarction among high-risk patients. Int J Med Sci. 2015; 12(4):329-335. https://doi.org/10.7150/ijms.11280

16. Powell J, DiLeo T, Roberge R, Coca A, Kim JH. Salivary and serum cortisol levels during recovery from intense exercise and prolonged, moderate exercise. Biol Sport. 2015; 32(2):91-95.https://doi.org/10.5604/20831862.1134314

17. Delacroix DL, Dive C, Rambaud JC, Vaerman JP. IgA subclasses in various se-cretions and in serum. Immunology. 1982; 47(2):383385.

18. Stephen KW, McCrossan J, Mackenzie D, Macfarlane CB, Speirs CF. Factors deter- mining the passage of drugs from blood into saliva. Br J Clin Pharmacol. 1980; 9(1):51-55. https://doi.org/10.1111/j.1365-2125.1980.tb04796.x 
19. Krishnan R, Thayalan DK, Padmanaban R, Ramadas R, Annasamy RK, Anandan N. Association of serum and salivary tumor necrosis factor-a with histological grading in oral cancer and its role in differentiating premalignant and malignant oral disease. Asian Pac $J$ Cancer Prev. 2014; 15(17):7141-7148. https://doi.org/10.7314/APJCP.2014.15.17.7141

20. Kuehl MN, Rodriguez H, Burkhardt BR, Alman AC. Tumor necrosis factor-a, matrix-metalloproteinases 8 and 9 levels in the saliva are associated with increased hemo-globin A1c in type 1 diabetes subjects. PLOS ONE. 2015; 10(4):e0125320. https://doi.org/10.1371/ journal.pone. 0125320

21. Pfaffe T, Cooper-White J, Beyerlein P, Kost- ner K, Punyadeera C. Diagnostic potential of saliva: current state and future applications. Clin Chem. 2011; 57(5):675-687. https://doi.org/10.1373/clinchem.2010.153767

22. Yoon AJ, Cheng B, Philipone E, Turner R, Lamster IB. Inflammatory biomarkers in saliva: assessing the strength of association of diabetes mellitus and periodontal status with the oral inflammatory burden. J Clin Periodontol. 2012; 39(5):434-440. https://doi. org/10.1111/j.1600-051X.2012.01866.x

23. Prasad S, Tyagi AK, Aggarwal BB. Detection of inflammatory biomarkers in saliva and urine: potential in diagnosis, prevention, and treatment for chronic diseases. Exp Biol Med (Maywood). 2016; 241(8):783-799. https://doi.org/10.1177/1535370216638770

24. Nater U, Rohleder N. Salivary alpha-amylase as a noninvasive biomarker for the sympathetic nervous system: current state of research. Psychoneuroendocrinology. 2009; 34(4):486-496. https://doi.org/10.1016/j.psyneuen.2009.01.014

25. Lee KC, Bassiur JP. Salivary Alpha Amylase, Dental Anxiety, and Extraction Pain: A Pilot Study. Anesth Prog. 2017; 64(1):22-28. https://doi.org/10.2344/anpr-63-03-02

26. Chaturvedi Y, Chaturvedy S, Marwah N, Chaturvedi S, Agarwal S, Agarwal N. Salivary Cortisol and Alpha-amylase-Biomarkers of Stress in Children undergoing Extraction: An in vivo Study. Int J Clin Pediatr Dent. 2018; 11(3):214-218. https://doi.org/10.5005/ jp-journals-10005-1514

27. Gutiérrez-Corrales A, Campano-Cuevas E, Castillo-Dalí G, Serrera-Figallo MÁ, Torres-Lagares D, Gutiérrez-Pérez JL. Relationship between salivary biomarkers and postoperative swelling after the extraction of impacted lower third molars. Int J Oral Maxillofac Surg. 2017; 46(2):243-249. https://doi.org/10.1016/j.ijom.2016.10.005

28. Humphris GM, Morrison T, Lindsay SJ. The Modified Dental Anxiety Scale: validation and United Kingdom norms. Community Dent Health. 1995; 12(3):143-150.

29. Leitch J, Macpherson A. Current state of sedation/analgesia care in dentistry. Curr Opin Anaesthesiol. 2007; 20(4):384-387. https://doi. org/10.1097/ACO.0b013e32825ea2a4

30. Robles TF, Sharma R, Park KS, Harrell L, Yamaguchi M, Shetty V. Utility of a salivary biosensor for objective assessment of sur-geryrelated stress. J Oral Maxillofac Surg. 2012; 70(10):2256-2263. https://doi.org/10.1016/j.joms.2012.03.005

31. Furlan NF, Gavião MB, Barbosa TS, Nicolau J, Castelo PM. Salivary cortisol, alpha-amylase and heart rate variation in response to dental treatment in children. J Clin Pediatr Dent. 2012; 37(1):83-87. https://doi.org/10.17796/jcpd.37.1.n32m21n08417v363

32. Strahler J, Skoluda N, Kappert MB, Nater UM. Simultaneous measurement of salivary cortisol and alpha-amylase: Application and recommendations. Neurosci Biobehav Rev. 2017; 83:657-677. https://doi.org/10.1016/j.neubiorev.2017.08.015

33. Chatterton RT, Vogelsong KM, Lu YC, Ellman AB, Hudgens GA. Salivary $\alpha$-amylase as a measure of endogenous adrenergic activity. Clin Physiol. 1996; 16(4):433-448. https://doi.org/10.1111/j.1475-097X.1996.tb00731.x

34. Gordis EB, Granger DA, Susman EJ, Trickett PK. Salivary alpha amylase- cortisol asymmetry in maltreated youth. Horm Behav. 2008; 53(1):96-103. https://doi.org/10.1016/j.yhbeh.2007.09.002

35. Allwood M, Handwerger K, Kivlighanc K, Granger D, Stroude L. Direct and moderating links of salivary alphaamylase and cortisol stress-reactivity to youth behavioral and emotional adjustment. Biol Psychol. 2011; 88(1):57-64. https://doi.org/10.1016/j. biopsycho.2011.06.008

36. Kang Y. Psychological stress-induced changes in salivary alpha-amylase and adrenergic activity. Nurs Health Sci. 2010; 12(4):477484. https://doi.org/10.1111/j.1442-2018.2010.00562.x

37. Ogunlewe MO, James O, Ajuluchukwu JN, Ladeinde AL, Adeyemo WL, Gbotolorun OM. Evaluation of haemodynamic changes in hypertensive patients during tooth extraction under local anaesthesia. West Indian Med J. 2011; 60(1):91-95.

38. Fukayama H, Yagiela JA. Monitoring of vital signs during dental care. Int Dent J. 2006; 56(2):102-108. https://doi.org/10.1111/j.1875595X.2006.tb00081.x

39. Zivotic-Vanovic M, Marjanovic M. Examination of cardiovascular function variables in tooth extraction under local anesthesia. Vojnosanit Pregl. 2006; 63(1):43-47. https://doi.org/10.2298/VSP0601043Z

40. Alemany-Martínez A, Valmaseda-Castellón E, Berini-Aytés L, Gay-Escoda C. Hemodynamic changes during the surgical removal of lower third molars. J Oral Maxillofac Surg. 2008; 66(3):453-61.https://doi.org/10.1016/j.joms.2007.06.634

How to cite this article: Abdullah Tolga Şitilci, Selin Gaş, Şule Batu, Hümeyra Kocaelli Arıkan, Büşra Bozbay. The effect of conscious sedation on salivary alpha-amylase levels during third molar surgery. J Clin Med Kaz. 2020; 2(56):11-16 